\title{
Land Suitability Evaluation for the Growth of Chamaecyparis obtusa Forest in Gyeongnam Province, South Korea
}

\author{
Moon Hyun Shik ${ }^{1}$, Tamirat Solomon ${ }^{1,2, *}$ \\ ${ }^{1}$ Department of Forest Environmental Resources, Institute of Agriculture and Life Science, Gyeongsang National University, Jinju, South \\ Korea \\ ${ }^{2}$ Department of Natural Resources Management, College of Agriculture, Wolaita Sodo University, Wolaita Sodo, Ethiopia
}

Email address:

hsmoon@gnu.ac.kr (M. H. Shik), tasolmame@gmail.com (T. Solomon)

${ }^{*}$ Corresponding author

\section{To cite this article:}

Moon Hyun Shik, Tamirat Solomon. Land Suitability Evaluation for the Growth of Chamaecyparis obtusa Forest in Gyeongnam Province, South Korea. Agriculture, Forestry and Fisheries. Vol. 9, No. 4, 2020, pp. 122-127. doi: 10.11648/j.aff.20200904.14

Received: July 16, 2020; Accepted: July 30, 2020; Published: August 17, 2020

\begin{abstract}
This study was conducted at eight different cities and counties of Gyeongnam province with the objective of evaluating the suitability of lands for the growth of Chamaecyparis obtusa (C. obtusa) species. From each city and county seven to ten sites were systematically selected for the study based on the regional representation of the sample sites by considering south, east, west and north regions of the province. From the selected sites soil data was collected by removing the top fertile soil in order to avoid the influence of decomposed top organic materials on the top soil. Soil samples from each site were air dried and the necessary laboratory processes undertaken. Evaluation of physiochemical characteristics was conducted by analyzing the properties of soil with growth requirement of the species. Storie parametric and FAO land evaluation methods were adopted to evaluate the parameters which were identified as important for the growth of the species. Based on the total index resulted from the parametric evaluation, suitability class was defined by assigning classes of highly suitable, (S1), moderately suitable (S2), marginally suitable (S3) and non-suitable (S4). The results of the study revealed that two study city/county were moderately suitable and the rest were categorized under marginally suitable for the growth and productivity of the species but there was no site which was categorized as highly suitable and non-suitable. It was recommended to use more silvicultural management for the areas categorized under marginally suitable in order to enhance the productivity.
\end{abstract}

Keywords: Suitable Land, Tree Growth, Soil Property, Silviculture, Forest Productivity

\section{Introduction}

Land suitability is defined as 'the fitness of a given type of land for a defined use' and land suitability evaluation (LSE) is the 'process of assessment of land performance for a specific purpose' [1,2]. Land suitability evaluation is an examination process of the degree of land suitability for a specific utilization type [3]. In forestry, the examination of land suitability and getting information about the status of land is needed to prioritize suitable forest plantation for land use development and efficiency on forest management decision making process [4]. Since, efficient yield forecasting and forest management requires a reliable measure of site productivity [5]. Consequently, in the changing climate identification of land for specific species growth is one of the key method for the sustainable production and management of forests.

As the national and international market demands increasing, forest production should emphasize on the identification of suitable land for production of plantation forests and sustainability of the existing forest stands. In this respect, the most important question raising for forest extension is about appropriate place or suitable land for afforestation and plant species establishment. South Korea, Japan, China and the Northeast Asia are characterized by a long history of forest management [6]. Hence, for the sustained production of forest resources knowledge of past and traditional management practices should be supported by 
scientifically, as past management practices may continue to influence ecosystem functions and processes for decades, centuries or even longer [7].

Therefore, one of the main ways of supporting the existing management systems by scientific method is through evaluation of land so as to identify the ideal species for the specific area [8]. Beside to the enhancement of productivity, land suitability evaluation has an economic benefit in cost minimization through reducing expenses while shortening the time of production of the yield. It also provides information on the constraints and opportunities for the use of the land and therefore guides decisions on optimal utilizations of resources, whose knowledge is an essential prerequisite for land use planning and development [8-10]. Thus, defining the relationship between soil characteristics and crop requirements must be the first step in planning future land use [11]. In this study we conducted the land suitability evaluation for the growth and expansion of Chamaecyparis obtusa species in Gyeongnam province S. Korea.

\section{Materials and Methods}

Location of the study area: The study was conducted at eight cities and counties of the Gyeongnam province of $\mathrm{S}$. Korea. Selection of the study areas was based on the regional representation of the province (South, North, East and West) by considering Jinju city as a center of reference (Figure 1).

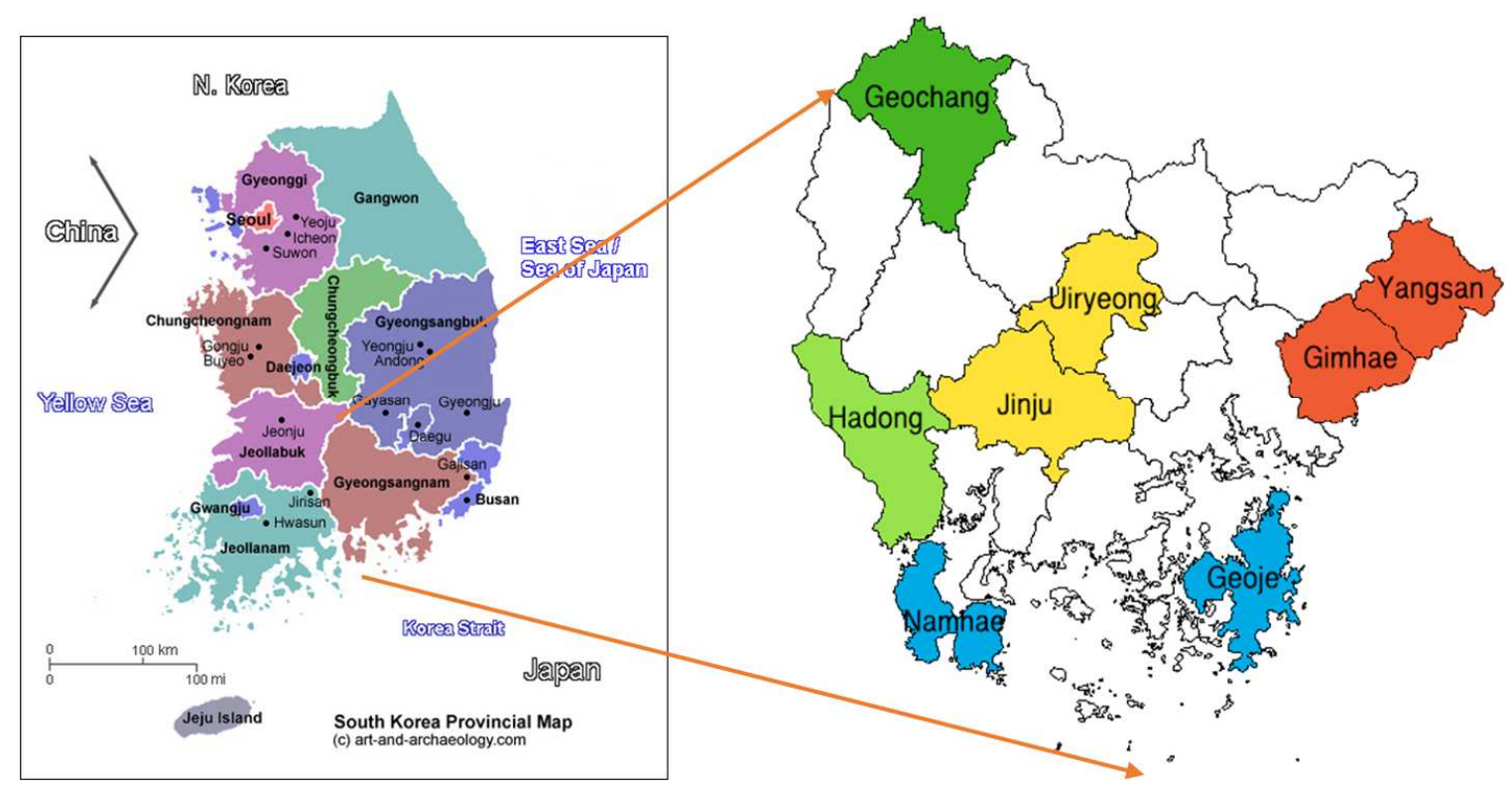

Figure 1. Locations of the study areas (Shaded areas represent sample study cities and counties).

Table 1. Description of background information of the study areas.

\begin{tabular}{|c|c|c|c|c|c|}
\hline Site & Altitude (m) & Slope (\%) & Aspects & Appearances & Land feature \\
\hline Hadong & $70-650$ & $5-15$ & $\mathrm{~N}, \mathrm{SW}$ & Ridge \& Valley & Mountainous \\
\hline Gimhae & $60-438$ & $5-20$ & SE,W & Ridge \& Bevel & Mountainous \\
\hline Jinju & $62-195$ & $5-20$ & E,NW & Ridge \& Bevel & Mountainous \\
\hline Geochang & $263-465$ & $5-15$ & SE,S & Ridge \& Bevel & Mountainous \\
\hline Namhae & $141-233$ & $5-20$ & NE,E & Bevel \& Valley & Mountainous \\
\hline Yangsan & $128-603$ & $10-15$ & W,SE & Bevel & Mountainous \\
\hline Uiryeong & $36-164$ & $15-20$ & SW,N & Bevel & Mountainous \\
\hline Geoje & $23-290$ & $10-30$ & W,NE & Bevel & Mountainous \\
\hline
\end{tabular}

$\mathrm{N}=$ north, $\mathrm{NE}=$ northeast, $\mathrm{SW}=$ southwest, $\mathrm{NW}=$ northwest, $\mathrm{S}=$ south, $\mathrm{W}=$ west, $\mathrm{E}=$ east, $\mathrm{SE}=$ south east.

\subsection{Methods of Data Collection}

Soil data was collected from a $20 * 20 \mathrm{~m}$ sample quadrats designed for the inventory of C. obtusa stand. A total of 72 sample quadrats were used across the entire sample cities and counties and about seven to ten sites were selected from each study city and county. Soil samples were collected by using soil digging hoe and hand tools by removing top organic soil up to $10-15 \mathrm{~cm}$. The sampled soils were placed separately in polythene bags and taken to laboratory.

The classification of lands suitable for the specific plant species stand takes into account the topographical, soil and climatic factors [12]. The important land characteristics in any land evaluation includes topography, soil, and climate; and especially topography and soil, are important components in determining land units [13]. Consequently, soil properties and slope condition of the study areas were considered for the study. 


\subsection{Determination of Criteria Influencing Land Suitability for C. obtusa Species}

As a growth of a tree varies with resources availability, the parameters for the evaluation of land suitability was determined by different facts from literatures taking into account the soil and topographic requirements of the species [14]. In evaluating the qualitative land suitability, land properties were compared with the corresponding plant requirements. There is a little information known about the growth preference of Hinoki cypress species. Hinoki cypress (Chamaecyparis obtusa) prefers moist but well-drained, loamy soil, somehow acidic for optimum health, full sun is best, but the tree can also grow in light shade $[15,16]$.

\subsection{Data Analysis}

\subsubsection{Soil Analysis}

For the analysis of the data the following procedures were followed. All the soil samples were air dried and passed through $2 \mathrm{~mm}$-sieves to obtain fine earth separates. From each soil sample of different study areas, over $5 \mathrm{mg}$ fine soil samples were prepared and measured for the moisture content and dried at $105^{\circ} \mathrm{C}$ for $12 \mathrm{hrs}$ and measured again for its dry weight.

The soil moisture content (\%) was measured by the following formulae [17].

$$
\mathrm{MC}(\%)=\frac{(B-C)}{(B-A)} * 100
$$

Where $\mathrm{A}=$ cup weight, $\mathrm{B}=$ cup weight plus soil weight and $\mathrm{C}=105^{\circ} \mathrm{C}$ heated cup and soil weight.

On the other hand, the organic matter content $(\%)$ of the soil was evaluated by $\mathrm{OM} \%=0.458 *$ L.O.I (\%)- 0.4 . Loss on ignition (LOI) is one of the most widely used methods for measuring organic matter content in soils [18].

$$
\text { Thus, LOI }(\%) ; \frac{(\mathrm{C}-\mathrm{D})}{(\mathrm{C}-\mathrm{A})} * 100
$$

Where $\mathrm{A}=$ cup weight, $\mathrm{B}=$ cup weight plus soil weight and $\mathrm{C}=105^{\circ} \mathrm{C}$ heated cup and soil weight and $\mathrm{D}=450^{\circ} \mathrm{C}$ heated cup and soil weight.

For the determination of soil $\mathrm{pH} 5 \mathrm{gm} \mathrm{1:5}$ ratio of soil and water $(5 \mathrm{~g}: 25 \mathrm{ml})$ was shake for 30 minutes and the soil $\mathrm{pH}$ was measured by $\mathrm{pH}$ meter, Orion, USA. In total seventy two soil samples were collected from the selected study sites for analysis of soil texture, soil $\mathrm{pH}, \mathrm{EC}(\mathrm{cmol}+/ \mathrm{kg}$ of soil), cations exchange capacity (CEC), and soil available phosphorous.

\subsubsection{Land Classification and Evaluation}

For the evaluation of land for its suitability for the growth of C. obtusa species assessment and grouping of land types in orders and classes was done separately by using a Storie parametric methods $[19,20,21]$. Rating of the parameters were undertaken by following the modified Storie index [22]. The land suitability problem was summarized in a generic model as in the following function:

$$
\mathrm{S}=f\left(x_{1}, x_{2}, x_{3}, \ldots \ldots x_{n}\right)
$$

Where $\mathrm{S}$ is suitability level and $x_{1}, x_{2}, x_{3}, \ldots \ldots x_{n}$ are the factors affecting land suitability [21].

The following measurement formulae was used to evaluate these characteristics:

Storie method:

$$
\mathrm{I}=A \times\left(\frac{A}{100} \times \frac{B}{100} \times \frac{C}{100} \times \frac{D}{100} \times \frac{E}{100} \times \frac{F}{100}\right)
$$

Where, $\mathrm{I}$ is the specified land index and $\mathrm{A}, \mathrm{B}, \mathrm{C} \ldots$ are degrees of different properties of parameters.

For the final index and definition of suitability classification, the criteria made by FAO framework [12, 23] using specific guidelines for definitions of orders ( $\mathrm{S}$ and $\mathrm{N}$ ) and classes (S1, S2, S3 and N) was used. Finally, the land suitability class for the species was made based on soil and topographic parameters.

\section{Results and Discussions}

\subsection{Properties of the Studied Soils}

Changes in the soil community affects the growth and survival of individual plants, and soil properties status may lead to differential growth of tree species [24, 26]. Soil texture influences the three basic factors in forest growth: soil moisture, aeration and soil nutrients $[26,27]$. In this study the soil texture of the study areas was loam, fine sandy loam and sandy loam. These soil types are generally more desirable than coarsetextured soils because of their superior retention of nutrients and water $[28,29]$. The soil texture types promoted the growth of conifers tree by enhancing the capacity of gross and net photosynthesis and dark respiration capacity [30]. A sandy loam soil tend to favor growth of trees [31]. These implies that the soil texture of the study areas are suitable for the growth of the species in comparison with nutrient requirement of the species $C$.

\begin{tabular}{|c|c|c|c|c|c|}
\hline City/County & MC (\%) & OM (\%) & $\mathrm{pH}\left(\mathrm{H}_{2} \mathrm{O}\right)$ & CEC (cmol+/kg) & Avail. P (ppm) \\
\hline Hadong & $23.6 \pm 0.47 b$ & $4.1 \pm 0.09 b$ & $4.1 \pm 0.02 \mathrm{e}$ & $16.9 \pm 1.37 \mathrm{~b}$ & $54.0 \pm 2.4 \mathrm{a}$ \\
\hline Gimhae & $20.4 \pm 0.36 \mathrm{~d}$ & $2.8 \pm 0.10 \mathrm{c}$ & $4.0 \pm 0.02 \mathrm{f}$ & $13.1 \pm 1.10 \mathrm{~d}$ & $24.0 \pm 1.6 \mathrm{c}$ \\
\hline Jinju & 13. $6 \pm 0.04 f$ & $4.9 \pm 0.16 \mathrm{a}$ & $4.5 \pm 0.02 \mathrm{~d}$ & $18.2 \pm 3.73 \mathrm{a}$ & $30.3 \pm 0.8 b$ \\
\hline Geochang & $17.4 \pm 0.23 \mathrm{e}$ & $1.3 \pm 0.05 \mathrm{~d}$ & $4.6 \pm 0.05 \mathrm{c}$ & $14.4 \pm 0.90 \mathrm{e}$ & $30.0 \pm 2.2 b$ \\
\hline Namhae & $21.8 \pm 0.19 c$ & $2.7 \pm 0.05 \mathrm{c}$ & $4.7 \pm 0.01 \mathrm{c}$ & $13.1 \pm 0.73 \mathrm{e}$ & $19.3 \pm 1.0 \mathrm{c}$ \\
\hline Yangsan & $25.2 \pm 0.61 \mathrm{a}$ & $3.0 \pm 0.07 \mathrm{c}$ & $4.5 \pm 0.02 \mathrm{~d}$ & $15.5 \pm 1.27 \mathrm{c}$ & $19.3 \pm 0.6 \mathrm{~d}$ \\
\hline Geoje & $22.5 \pm 0.25 c$ & $3.0 \pm 0.09 \mathrm{c}$ & $4.7 \pm 0.01 \mathrm{~b}$ & $12.9 \pm 1.26 \mathrm{f}$ & $22.2 \pm 1.0 \mathrm{c}$ \\
\hline
\end{tabular}
obtusa as the loamy soils are ideal for plant growth, drains well, full of nutrients and holds water.

Table 2. Average chemical properties of the studied soil profiles. 


\subsection{Suitability Classification}

Table 3 shows a suitability classification of the eight cities and counties included in the study. The major factors which regulated the suitability of the study areas for the C. obtusa species were moderately acidic property of the soil. Soil $\mathrm{pH}$ influences nutrient uptake and tree growth, also soil reaction $(\mathrm{pH})$, in particular, can be considered as a key variable due to its influence on many other soil proprieties and processes affecting plant growth $[32,33]$. Thus, levels of soil $\mathrm{pH}$ can be used as a general guide for determining what species will grow on a given site and are typically indicative of available nutrient levels [34]. In the study areas, most sites were having a strong $\mathrm{pH}$ level ranging (4-4.7), however, due to the nature of the species C. obtusa and it is requirements for optimum growth, the acidic nature of the soil is recommendable for the plantation expansion [16].

Phosphorus is one of the most important factors influencing the growth and quality of plantations [35]. Despite few of the sites showed lower soil available phosphorous, there was a relatively similar amount of the nutrient at all the study areas (Table 2). Relative to other macronutrients, phosphorous concentration in the soil is considerably less [36]. Therefore, due to its importance to the plant growth, amendment of $\mathrm{P}$ in the nursery and time of silvicultural management could enhance the productivity mainly at sites categorized under sub-class S3 [37].

Table 3. Suitability classification for the growth of C. obtusa species.

\begin{tabular}{llll}
\hline City/county & Order & Class & Sub-class \\
\hline Hadong & S & Suitable & S2 (moderately suitable) \\
Geochang & S & Suitable & S3 (marginally suitable) \\
Jinju & S & Suitable & S2 (moderately suitable) \\
Gimhae & S & Suitable & S3 (marginally suitable) \\
Namhae & S & Suitable & S3 (marginally suitable) \\
Yangsan & S & Suitable & S3 (marginally suitable) \\
Uiryeong & S & Suitable & S3 (marginally suitable) \\
Geoje & S & Suitable & S3 (marginally suitable) \\
\hline
\end{tabular}

The most common physiographic measures of forest site productivity are slope, aspect, elevation, latitude and longitude as due to these factors, productivity frequently various at different sites [38]. In plantation forest growth slope resulted a significant effect on the height- DBH relationships [39]. This is due to the capacity of slopes in modifying microclimate, soil microbial community and influencing ecological processes and spatial distribution of species across forest landscape [40, 41]. Slope and aspect cause the impact on light trees need for growth and affects the forest productivity, thus, higher level of slope reduces the suitability of the land for growth of the species [42].

Organic matter plays a determining role in pedogenesis and can drastically modify the physical, chemical, and biological properties of soil (structure, plasticity, colour, water retention, CEC, and AEC) [43]. A good supply of soil organic matter acts positively on root growth, because it reduces soil resistance to root penetration and increases the water retention capacity [44]. From the result of the current study there was variation on the organic matter condition in the study areas. For instance, sites at different altitudinal rages at different cities and counties showed small amount of organic matter ranging less than five percent. For the identification of "right-site for the right-tree species" understanding of the species requirement for the optimum growth is top most important. Therefore, based on the parametric evaluation results, the following suitability class of the land for the growth of $C$. obtusa species has been developed.

Table 4. Land suitability class for Chamaecyparis obtusa growth based on soil and topographic parameters.

\begin{tabular}{llll}
\hline \multirow{2}{*}{ Parameters } & \multicolumn{3}{l}{ Degree of limitation } \\
\cline { 2 - 4 } & S1 & S2 & S3 \\
\hline $\mathrm{pH}$ & $>4.5-6$ & $>4$ & $3-4$ \\
Organic matter & $>7.2$ & $>1.23$ & $<1.23$ \\
Available phosphorous & $>0.9$ & $\geq 0.44$ & $<0.44$ \\
Slope & $5 \%$ & $5-10$ & $>10$ \\
Altitude & varies* & $>98$ m.a.s.l. & $<98$ m.a.s.1. \\
\hline
\end{tabular}

*more importantly it depends on soil properties

\section{Conclusion}

The present study analyzed the suitability of land condition for C. obtusa species by parametric approaches in Gyeongnam province of South Korea. The classes of land suitability for the species by the used approach was categorized into moderately and marginally suitable but no site was identified as non-suitable. The finding of the study can help in decision on the forest management methods including the application of silvicultural practices on the existing stands and further expansion of the species plantation in the province.

\section{References}

[1] Bandyopadhyay, S., Jaiswal, R. K., Hegde V. S. \& Jayaraman V. (2009). Assessment of land suitability potentials for agriculture using a remote sensing and GIS based approach. International Journal of Remote Sensing, 30:4, 879-895. https://doi:10.1080/01431160802395235.

[2] FAO. (1976). A Framework for Land Valuation FAO Soils Bulletin No. 32. 72. FAO, Rome, Italy.

[3] Sys, C. E. and Debaveye, J. (1991). Land evaluation, part 1: Principles in land evaluation and crop production calculation. In General administration for development cooperation. Agric. Pub.: 7:274. Brussels: Belgium.

[4] Kandari, A. M., Kasim, S., Limi, M. A. and Karim, J. (2015). Land Suitability Evaluation for Plantation Forest Development Based on Multi-criteria Approach. Agriculture, Forestry and Fisheries. 4:228-238. https://doi:10.11648/j.aff.20150405.15. 
[5] Vanclay, J. K. and Henry, N. B., (1988). Assessing Site Productivity of Indigenous Cypress Pine Forest in Southern Queensland. The Commonwealth Forestry Review. 67 (1). 5364 .

[6] Kim, S., Guanlin, L. and Son, Y. (2017). The Contribution of Traditional Ecological Knowledge and Practices to Forest Management: The Case of Northeast Asia. Review. Forests. 8: 496. doi: 10.3390/f8120496.

[7] Douda J., Boublik K., Doudova J., and Kyncl M. (2017). Traditional forest management practices stop forest succession and bring back rare plant species. Journal of applied ecology 57, 761-771.

[8] AbdelRahman, M. A. E., Natarajan, A., Hegde, R. (2016). Assessment of land suitability and capability by integrating remote sensing and GIS for agriculture in Chamarajanagar district, Karnataka, India. The Egyptian Journal of Remote Sensing and Space Science, 19:1. 125-141. https://doi.org/10.1016/j.ejrs.2016.02.001.

[9] Qu, L., Shao Y. and Zhang, L. (2013). Land Suitability Evaluation Method Based on GIS Technology. IEEE. 978-14799-0868-4. Second International Conference on AgroGeoinformatics (Agro-Geoinformatics). doi: 10.1109/Argoeoinformatics.2013.6621869.

[10] FAO, (2012). Natural Resource Assessment for Crop and Land Suitability: An Application for Selected Bioenergy Crops in Southern Africa Region. Rome, Italy.

[11] Vasu, D., Srivastava, R., Patil, N. G., Tiwary P., Chandran, P., Singh, S. K. (2018). A comparative assessment of land suitability evaluation methods for agricultural land use planning at village level. Land use policy, 79: 146-163. https://doi.org/10.1016/ j.landusepol.2018.08.007.

[12] FAO. (1984). Guidelines: Land evaluation for forestry. FAO Soils Bulletin, No. 48: 123. Rome.

[13] Ritung, S., Agus, F. W., Hidayat, H. (2007). Land Suitability Evaluation with a case map of Aceh Barat District. Indonesian Soil Research Institute and World Agroforestry Centre, Bogor, Indonesia.

[14] Toledo, M., Poorter, L., Pen 'a-Claros, M., Alarco'n, A., Balca'zar, J., Leaño, C., Licona, J. C., Llanque, O, Vroomans, V., Zuidema, P., Bongers, F. (2011). Climate is a stronger driver of tree and forest growth rates than soil and disturbance. Journal of Ecology.99: 254-264. https://doi:10.1111/j.13652745.2010.01741.x.

[15] Larum, D. (2018). False Cypress Care: How to Grow a False Cypress Tree. Gardening Know How. https:/www.gardeningknowhow.com/ornamental/trees/falsecypress/growing-hinoki-cypress.htm (accessed 11/01/2020).

[16] Park, S. G., You, H. C., Oh, C. J, Choi, W. K. (2015). Analysis of the Correlation between Site Environmental Factors and Tree Ring Growth in Chamaecyparis obtusa stands in Jeonnam Province. Korean Journal of Environ. Ecol. 29 (5): 777-784. https://doi.org/10.13047 /KJEE.2015.29.5.777.

[17] Sarkar, D. and Haldar, A. (2005). Physical and Chemical Methods in Soil Analysis. Fundamental concepts of analytical chemistry and instrumental techniques. New Age International. 139.

[18] Hoogsteen, M. J. J., Lantinga, E. A., Bakker, E. J., Groot, J. C. J. and Tittonell, P. A. (2015). Estimating soil organic carbon through loss on ignition: Effects of ignition conditions and structural water loss. Eur. J. Soil Sci. 66 (2): 320-328. https://doi:10.1111/ejss.12224.

[19] Storie, R. E. (1978). An index for rating the agricultural value of soils, Agricultural Experiment, Station Bulletin 556, University of California Agricultural Experiment Station, Berkley, CA.

[20] Mueller, L., Schindler, U., Mirschel, W., Shepherd, T. G., Ball, B. C. (2010). Assessing the productivity function of soils. A review. Agronomy for Sustainable Development, Springer Verlag/EDP $\quad$ Sciences/INRA, 2010, $30 \quad$ (3), ff1 0.1051/agro/2009057ff. ffhal-00886548f.

[21] Rabia, A. H. and Terribile, F. (2013). Introducing a New Parametric Concept for Land Suitability Assessment. Int. J. of Environmental Science and Development, 4:15-19. https://doi: 10.7763/IJESD.2013.V4.295

[22] O'Geen A. T., Southard S. B. and Southard R. J. (2008). A Revised Storie Index for Use with Digital Soils Information. UC Agriculture \& Natural Resources. 1-11. Doi: 10.3733/ucanr.8335.

[23] Dengiz, O., Gol, C., Sarioğlu, F. E. and Ediş, S. (2010). Parametric approach to land evaluation for forest plantation: A methodological study using GIS model. African Journal of $\begin{array}{llll}\text { Agri. } & \text { Research } & 5 & \text { (12): }\end{array}$ http://www.academicjournals.org/AJAR.

[24] Meijer S. S., Holmgren M., and Van der Putten W. H. (2011). Effects of plant-soil feedback on tree seedling growth under arid conditions. Journal of Plant Ecology. 4:4. 193-200. https://doi.org/10.1093/jpe/rtr011.

[25] Martinez-Garza C., Campo J., Ricker M., Tobón W. (2016). Effect of initial soil properties on six- year growth of 15 tree species in tropical restoration plantings. Ecology and Evolution, 6:8686-8694. https://doi.org/10.1002/ece3.2508.

[26] Wilde, S. A. (1935). The significance of soil texture in forestry, and its determination by a rapid field method. J. Forest. 33: 503-508. https://doi.org/10.1093/jof/33.5.503.

[27] Gilliam F. S., Yurish B. M. and Goodwin L. M. (1993). Community Composition of an Old Growth Longleaf Pine Forest: Relationship of Soil Texture. Bulletin of the Torrey Botanical Club, 120:3. 287-294.

[28] R. E. White, Principles and practice of soil science: the soil as a natural resource / Robert E. White. - 4th ed. Blackwell Publishing. 2006, 387.

[29] M. Lukac, and D. L. Godbold, Soil ecology in northern forests: a below ground view of a changing world. Cambridge University Press, New York. 2011, 274.

[30] Smith, D. W., (1970) "The effects of soil texture and soil moisture on photosynthesis, growth and nitrogen uptake of Scotch pine seedlings". Retrospective Theses and Dissertations. 4362. https://lib.dr.iastate.edu/rtd/4362

[31] Khan, M. L. and Tripathi, R. S. (1989). Effect of soil moisture, soil texture and light intensity on emergence, survival and growth of seedlings of a few sub-tropical trees. Indian Journal of Forestry, 12, 196-204.

[32] Londo, A. J., Kushla, J. D., and Carter, R. C. (2006). Soil pH and tree species suitability in the south. Southern Regional Extension Forestry SEFR-FM-002. 
[33] Gentili, R., Ambrosini, R., Montagnani, C., Caronni, S. and Citterio, S. (2018). Effect of Soil pH on the Growth, Reproductive Investment and Pollen Allergenicity of Ambrosia artemisiifolia L. Front. Plant Sci. 9:1335. https://doi:10.3389/fpls.2018.01335.

[34] A. B. Self, Soil pH and Tree Species Suitability in Mississippi. Extension Service of Mississippi State University, cooperating with U. S. Department of Agriculture. USA. 2016.

[35] Zeng, F., Chen, X., Huang, B., and Chi, G., (2018). Distribution Changes of Phosphorus in Soil-Plant Systems of Larch Plantations across the Chronosequence. Forests, 9: 563. Doi: 10.3390 / f9090563.

[36] Jobbagy E. G., and Jackson R. B., (2001). Distribution of soil nutrients with depth: Global patterns and the imprint of plants. Biogeochemistry, 53:51-77. https://doi:10.1023/A:1010760720215.

[37] Zavišić, A., Yang, N., Marhan, S., Kandeler, E., and Polle, A. (2018) Forest Soil Phosphorus Resources and Fertilization Affect Ectomycorrhizal Community Composition, Beech P Uptake Efficiency, and Photosynthesis. Front. Plant Sci. 9:463. http://doi:10.3389/ fpls.2018. 00463.

[38] A. R. Weiskittel, D. W. Hann, J. A. Jr. Kershaw, and J. K. Vanclay, Forest growth and yield modelling. John Wiley and Sons, Ltd. USA. 2011
[39] Long, S., Zeng, S., Liu, F., Wang, G. (2020). Influence of slope, aspect and competition index on the height-diameter relationship of Cyclobalanopsis glauca trees for improving prediction of height in mixed forests. Silva Fennica, 54:1. Id 10242. https://doi.org/10.14214/sf.10242.

[40] Aström, M., Dynesius, M., Hylander, K., Nilsson, C. (2007). Slope aspect modifies community responses to clear-cutting in boreal forests. Ecology. 88 (3):749 - 758. Doi: 10.1890/060613.

[41] Xue, R., Yang, Q., Miao, F., Wang, X., and Shen, Y. (2018). Slope aspect influences plant biomass, soil properties and microbial composition in alpine meadow on the QinghaiTibetan plateau. J. Soil Sci. Plant Nutr. 18 (1). Temuco mar. http://dx.doi.org/10.4067/S0718-95162018005000101.

[42] Kravkaz-Kuscu I. S., Sariyildiz T., Cetin M., Yigit N., Sevik H., Savaci G. (2018). Evaluation of the soil properties and primary forest tree species in Taskopru (Kastamonu) district. Fresenius Environmental Bulletin 27 (3): 1613-1617. https://doi.org/10.15244/ pjoes/ 78475.

[43] M. Pansu, and J. Gautheyrou, Handbook of Soil Analysis. Mineralogical, Organic and Inorganic Methods. SpringerVerlag Berlin Heidelberg. The Netherlands. 2006, 995.

[44] P. Baldaccini, and A. Vacca, Soil Suitability for Irrigation. In: Costantini E. A. C. (eds). Manual of methods for soil and land evaluation. Science Publishers. USA. 2009, 570. 